\title{
INTEGRATING INTERACTIVE FLASH ANIMATIONS AND JAVA APPLET IN LMS MOODLE
}

\author{
Martin MAGDIN
}

\begin{abstract}
The paper discuss about efficient and simple solution to the problem of integrating interactive flash animations and JAVA applet within LMS MOODLE. We created easy-to-use application for generating the HTML code, which is necessary for show files correctly in LMS MOODLE.
\end{abstract}

Key words: LMS MOODLE, interactivity, flash animations, JAVA applet, application FlashGen.

\section{INTEGRÁCIA INTERAKTÍVNYCH FLASH ANIMÁCIÍ A JAVA APPLETOV DO LMS MOODLE}

Resumé: V príspevku sa zameriavame na efektívne a jednoduché riešenie problému, ktorým je možnost' integrácie interaktivnych flash animácií a JAVA appletov do LMS MOODLE. Vytvorili sme preto aplikáciu generujúcu príslušný HTML kód, ktorý je potrebný pre správne zobrazovanie súborov $\checkmark$ LMS MOODLE.

Kl'účové slová: LMS MOODLE, interaktivita, flash animácie, JAVA applet, aplikácia FlashGen.

\section{1 Úvod}

Podpora súčasného vzdelávania formou e-learningu nie je len módny hit, či výstrelok nadšenca, ktorý by najradšej IKT integroval do každej časti vyučovacieho procesu, ale ide o vel'mi seriózny trend, ktorý vedie $\mathrm{k}$ digitalizácii tej najstaršej a najdôležitejšej formy poskytovania informácií prostredníctvom médií.

\section{LMS MOODLE}

LMS MOODLE (Modular Object Oriented Dynamic Learning Environment) je modulové objektovo orientované dynamické vzdelávacie prostredie, ktoré patrí medzi základné podporné systémy v oblasti e-learningu. Predstavuje vol'ne šíritel'ný softvér s možnostou dopíňania kódu postavený na báze PHP a SQL databáz. Pri štúdiu pomocou LMS MOODLE nám stačí pripojenie $\mathrm{PC}$ na LAN siet' (resp. Internet) a niektorý z internetových prehliadačov (MS IE, Mozila...). Materiál určený pre štúdium môže byt' prezentovaný súbormi rôzneho formátu, napr. *.doc, *.xls, *.ppt, *.html a podobne. Pomocou formátu html, resp. htm môžeme implementovat' na stránky kurzu obrázky, zvuky alebo videosekvencie. Pohl'ad na www stránky našich stredných a vysokých škôl prezrádza, že LMS MOODLE je najrozšírenejším LMS systémom na Slovensku [URL 1].

\section{Interaktivita v LMS MOODLE}

Problematikou implementácie interaktivity do elektronických kurzov sa v súčasnosti zaoberá viacero autorov (napr.: B. H. Banathy), ktorí zastávajú názor, že iba pomocou interaktivity je možné zabezpečit' to, o čo sa snaží kybernetika v spojení s didaktikou - teda o možnost' riadit' výučbu.

Každý zo súčasných LMS systémov už štandardne podporuje implementáciu mediálnych prvkov do elektronických kurzov, avšak nie každý z nich poskytuje aj možnost' interaktivity študujúceho spolu so študijným materiálom, ktorý kurz obsahuje. Neraz sa preto môžeme stretnút' s neochotou vytvárania kvalitných kurzov (často sú nimi aj samotní lektori, učitelia), ktorý argumentujú tým, že nebudú predsa predkladat' svoje materiály $\mathrm{v}$ elektronickej podobe, ked' sú k dispozícii v papierovej (skriptá).

Študenti stredných škôl v SR sú prevažne zvyknutí na kompletný výklad učiva, frontálne preskúšanie počas hodiny aj školského roka a menšie možnosti využívania internetu na vzdelávacie účely. Väčšina $\mathrm{z}$ nich ani netuší o možnostiach e-learningového vzdelávania a hodnotenia. Preto pristupujú $\mathrm{k}$ používaniu multimediálnych pomôcok a prípadnej e-learningovej podpore ako k novinke, ktorá dokáže vzbudit' o takýto druh výučby záujem, o elektronickú formu učenia a učebníc vôbec. Naopak pre študentov vysokých škôl, je 
používanie multimediálnych pomôcok a elektronických kurzov viac-menej samozrejmost'ou, ked'že sa od nich automaticky očakáva využívanie ich intelektuálnych a kognitívnych schopností tak, aby dochádzalo $\mathrm{k}$ ich autoaktivite, na ktorú sú zvyknutí práve pri používaní elektronických kurzov.

Tento fakt je možné odstránit' pomocou interaktivity, ktorá je jedným zo základných prvkov multimédií a je tak posledným krokom $\mathrm{k}$ ich dokonalosti, ked’že ovplyvňuje chovanie a výsledný výstup systému. Podl’a [1] je potrebné aby bola podmienená existenciou spätnej väzby pre posielanie požiadaviek tým, že bude predstavovat' priame a aktívne vstupovanie do systému zaručujúce tvorivost'. Je preto vel'mi dôležité, aby nespočívala len vo výbere odpovedí z ponúknutých možností, či v schopnosti spustit' alebo zastavit' animáciu.

\section{Flash animácie v LMS MOODLE}

Animácie vytvorené pomocou grafického programu Adobe Flash nám ponúkajú nielen možnost' interaktivity $\mathrm{v}$ kurze, ale tiež nám ponúkajú možnost' simulovania procesov. Pomocou grafického programu Adobe Flash je možné napr. vytvorit' interaktívnu animáciu, pri ktorej dynamicky, prechodom myši po jednotlivých častiach obrázku meníme jeho obsah (obr. 1). Taktiež takto vytvorená animácia zaberá menšiu čast' obrazovky, a teda ju môžeme prípadne doplnit' dodatočným výkladom napr. $\mathrm{v}$ podobe textu.

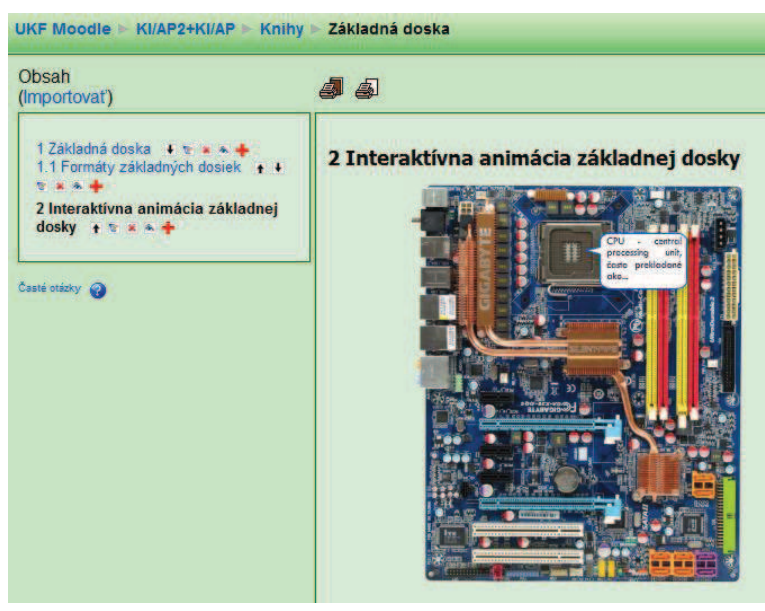

Obr. č. 1: Interaktívna animácia základnej dosky.

\section{JAVA applety a interaktívne typy úloh $\checkmark$ LMS MOODLE}

Interaktivitu v elektronických kurzov môžeme dosiahnut' aj pomocou vkladania JAVA apletov. Aj ked' táto technológia zažila svoj najväčší boom na konci 90 -tych rokov 20 storočia, stále má svojich priaznivcov.

Pomocou JAVA appletov je možné vložit' nielen prvky interaktivity do elektronického kurzu, ale môžeme vytvorit' tzv. interaktívne typy úloh, a výsledky $\mathrm{z}$ nich poslat' učitel'ovi na hodnotenie. Všetko závisí od spôsobu, akým sú interaktívne typy úloh vytvorené. Vo všeobecnosti existujú dva základné spôsoby, akými môžeme zabezpečit', aby sa výsledky pri vypracovávaní interaktívnej otázky, resp. interaktívneho typu úlohy odosielali na server LMS systému a zapisovali priamo do databázy.

Prvý zo spôsobov predstavuje posielanie súborov podobne ako je to aj pri klasickom formulári v HTML. Odoslanie spočíva v zavolaní skriptu (čo je ekvivalentné otvoreniu URL skriptu), ktorý potom súbor prijme a uloží na server. Problém, ktorý sa pri takomto riešení črtá, vychádza najmä z obmedzenia appletu, že skript musí byt' uložený na rovnakom serveri ako applet, sám o sebe môže otvárat' iba stránky zo servera, z ktorého bol stiahnutý. Taktiež nie je možné jednoduchým spôsobom odoslat' súbor z lokálneho disku, ked’že applet nemôže pristupovat' $\mathrm{k}$ súborom na disku.

Toto sa však dá obíst' digitálnym podpísaním appletu, kedy si používatel' pri stiahnutí appletu môže overit', že applet pochádza od skutočného autora a tiež môže povolit' vyššie privilégiá pre applet. Pre nás však táto možnost' nie je vel'mi zaujímavá, pretože nepotrebujeme posielat' súbory nachádzajúce sa na disku. Nám stačí odoslat' dáta, ktoré má applet vytvorené v pamäti - teda výsledné overenie správnosti vypracovania interaktívneho typu otázky. A to zvládne aj applet, ktorý nie je digitálne podpísaný.

Druhým spôsob je značne problematický, ale zato jeho použitie je efektívnejšie a jednoduchšie oproti prvému riešeniu. Vychádza z možnosti vytvárania modulov a ich implementácie do jednotlivých LMS systémov. Ked’že podl'a štatistiky viac ako 90 \% škôl (od základných až po vysoké školy) využíva open-source LMS systém Moodle, zamerali sme sa na vývoj a implementáciu modulu interaktívna otázka. Tento modul sa vyvíja $v$ rámci projektu UGA na Katedre informatiky FPV UKF v Nitre. Výsledkom je tak ,jednoduché“ riešenie vyhodnocovania interaktívneho testovania 
študentov, pričom výsledky sa zapisujú do databázy a teda aj do celkového hodnotenia študentov.

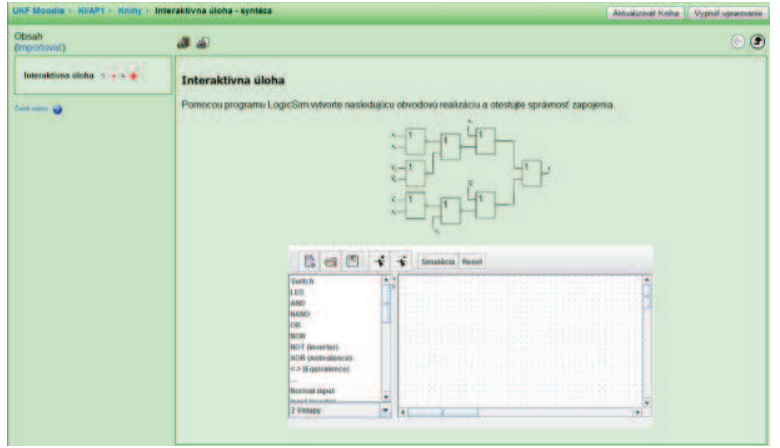

Obr. č. 2: JAVA applet - správna odpoved'sa vyhodnocuje na základe zápisu do databázy.

\section{Vkladanie animácií a appletov prostredia LMS MOODLE}

do

Vkladanie flash animácií a java appletov do LMS MOODLE je spojené s niekol'kými problémami, a preto používame možnost' ich vloženia pomocou HTML kódu. LMS MOODLE však pri vytvorení obsahu kontroluje správny zápis HTML kódu, a preto naša animácia alebo applet sa vôbec nezobrazí, alebo pri d'alšej úprave nám jednoducho zmizne. Pre urýchlenie vkladania Flash animácií sme vytvorili jednoduchú aplikáciu „MOODLE FlashGen HTML“, ktorá nám potrebný HTML kód vygeneruje. Rozhranie aplikácie je jednoduché (obr. 4) a obsahuje rôzne polia, ktoré je potrebné vyplnit', inak sa animácia alebo applet nezobrazí:

a) Meno klipu - pomenovanie flash animácie, možno použit' l'ubovol'né označenie

b) Śírka klipu - určenie akú šírku má mat' výsledný klip v pixeloch

c) Výška klipu - určenie akú šírku má mat' výsledný klip v pixeloch

d) Cesta ku klipu - definuje kompletnú cestu ku zdrojovému swf úboru

Okrem tejto aplikácie a základných informácií ako meno klipu, šírka a výška klipu, potrebujeme vediet' umiestnenie swf animácie, ktorú ak chceme použit' vLMS MOODLE, si musíme najskôr nahrat' do súborov kurzu (obr. 3) a následne skopírovat' adresu umiestnenia animácie - v našom príklade je http://edu.ukf.sk/file.php/163/Motherboard/dostic ka.swf.

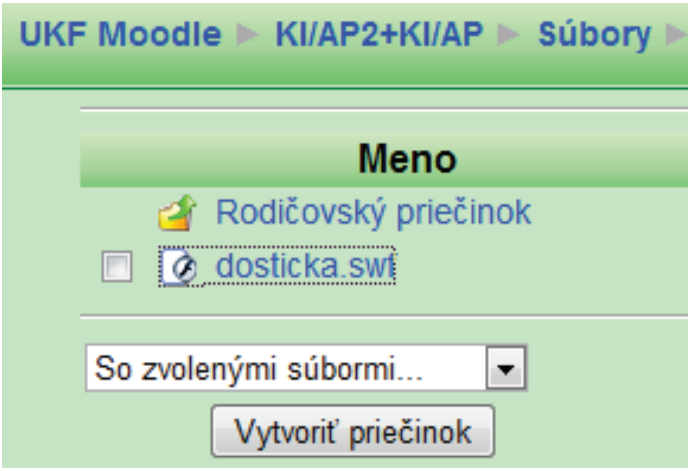

Obr. č. 3: swf súbor v LMS MOODLE.

Po vyplnení príslušných položiek v aplikácií a potvrdení tlačidla generuj (obr. 4), získame potrebný HTML kód pre správne integrovanie flash animácie do LMS MOODLE.

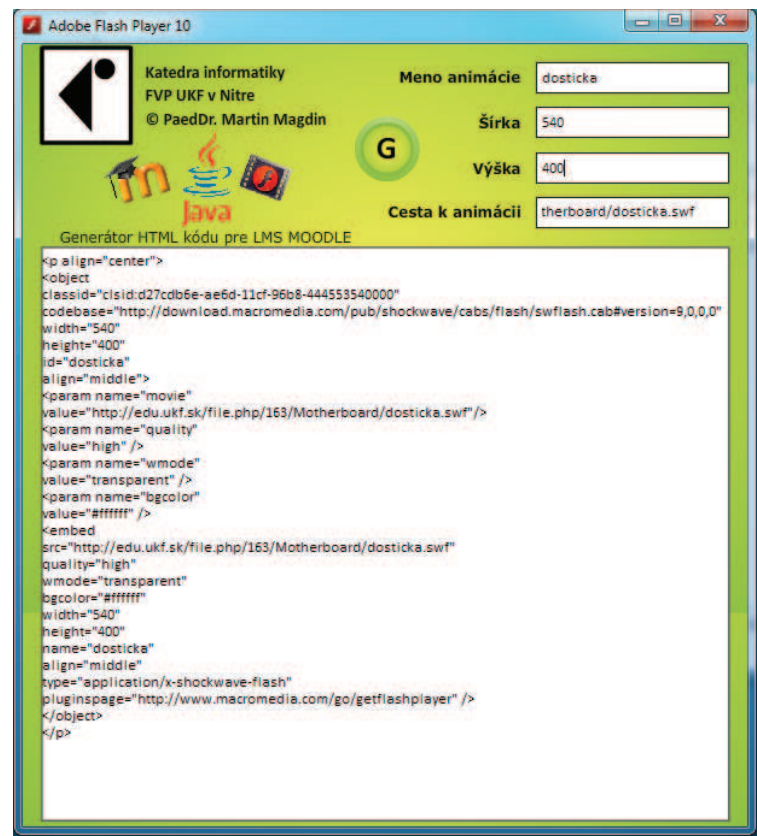

Obr. č. 4: Vygenerovaný kód HTML pomocou aplikácie FlashGen.

Kód vkladá animáciu do tagu $<\mathrm{p}></ \mathrm{p}>$ a zarovnáva ho do stredu (align="center"), pozadie animácie je prednastavené ako transparentné. Vygenerovaný HTML kód je potrebné označit', skopírovat' a vložit' do editačného okna v LMS MOODLE (obr. 5).

Ked’že LMS MOODLE kontroluje a upravuje výsledný HTML kód obsahu pri vkladaní flash animácie, nesmieme prepnút' editor spät' do WYSIWYG módu, ale musíme obsah uložit' priamo z HTML módu. 


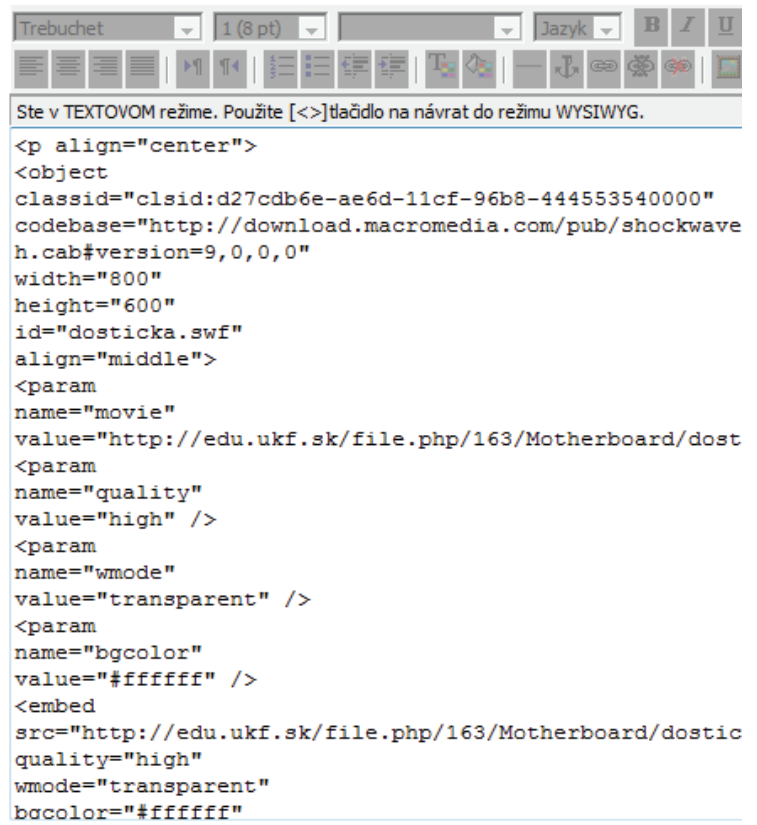

Obr. č. 5: HTML kód v editore LMS MOODLE.

Podobne postupujeme aj pri vkladaní JAVA appletov, alebo flv formátu (flash video), pre ktoré táto aplikácia umožňuje vygenerovat' potrebný kód. Pri JAVA appletoch je potrebné zadat' viac vstupných informácií, ako pri flash animáciách, avšak výsledný kód je značne jednoduchší:

a) Meno binárneho súboru - je jednoznačne dané programátorom daného appletu, teda nemôže byt' l'ubovol'né

b) Šírka - určenie šírky zobrazeného appletu $\mathrm{v}$ pixeloch

c) Výška - určenie výšky zobrazeného appletu $\mathrm{v}$ pixeloch

d) Cesta k appletu - definuje kompletnú cestu ku zdrojovému súboru (appletu)

e) Adresár appletu - miesto na serveri, kde je applet umiestnený

f) Názov appletu - pomenovanie appletu, môže byt' l'ubovol'né.

\section{Záver}

V súčasnosti už existuje celá rada podporných multimediálnych nástrojov použitel'ných vo vzdelávaní. Vytváranie a implementácia modulov do prostredia LMS MOODLE predstavuje schopnost' realizovat' plne interaktívne virtuálne vzdelávacie prostredie, pričom jeho najdôležitejšou vlastnost'ou je možnost' riadit' výučbu ako z pohl'adu študenta, tak aj z pohl'adu vyučujúceho, pri využití nielen vzájomnej interakcie, ale aj interakcie študujúceho spolu so študijným textom, resp. samotným systémom.

Veríme, že najrozšírenejší systém on-line podpory vzdelávania - LMS MOODLE, s použitím interaktívnych animácií prispeje k skvalitneniu a zefektívneniu vzdelávania ako na stredných, tak aj na vysokých školách a pomôže tak mnohým študentom pri získavaní vedomostí $\mathrm{z}$ rôznych oblastí.

\section{Literatúra}

[1] SUDOLSKÁ, M., POMFFYOVÁ, M.: Vybrané kapitoly $\mathrm{z}$ didaktiky informatiky. 1.vydanie. Bratislava: Metodicko-pedagogické centrum. 2006. ISBN 80-8052-266-9

[URL 1] KAPUSTA, J. - SKALKA, J TURČ́ANI, M.: Chýba vám niečo v Moodle? Tak si to doprogramujte!. In Spolupráce univerzit při efektivní tvorbě a využívání vzdělávacích zdroju. Praha : ČVUT Praha, 2006, s. 37-42. ISBN 80-239-6601-4.

[URL 2] http://www.uniba.sk/index.php?i $\mathrm{d}=1310$ [online] [cit. 2009-03-20]

[URL 3] http://moodle.org/mod/data/view. php?id=7246 [online]

http://www.adobe.com/devnet/flash/?view=quick start [online]

PaedDr. Martin Magdin

Katedra informatiky, Fakulta prírodných vied Univerzita Konštantína Filozofa v Nitre

Trieda A. Hlinku 1

949 01, Nitra, SR

E-mail: mmagdin@ukf.sk, www pracovisko: www.ki.fpv.ukf.sk 